\title{
Effect of Cattle Menace on Farm Land in Anambra State, Niger IA
}

\author{
Udemezue JC ${ }^{1 *}$ and Nwalieji $\mathrm{HU}^{2}$ \\ ${ }^{1}$ National Root Crops Research Institute, Umudike, Nigeria \\ ${ }^{2}$ Department of Agricultural Economics and Extension, Chukwuemeka Odumegwu Ojukwu University, Nigeria
}

Submission: August 04, 2017; Published: August 24, 2017

*Corresponding author: Udemezue JC, National Root Crops Research Institute, Umudike, PMB7006 Umudike Abia State, Nigeria, Tel: 08038971076; Email: udemezuej@gmail.com

\begin{abstract}
The study examined the effect of cattle menace on farm land in Anambra State, Nigeria. The population included all crop farmers in the state. Multistage and simple random sampling techniques were used to select a total sample size of 160 farmers. An interview schedule was used for data collection and descriptive statistics such as percentage, mean and standard deviation were used in presenting data. Findings show that mean age, household size, farm size and farming experience of the crop farmers were 41.31 years, 7 persons, 1.8 hectares and 16.4 years, respectively. Loss of soil fertility ( $\mathrm{M}$ a 2.59), environmental pollution $(\mathrm{M}=2.50)$ and crop destruction/failure $(\mathrm{M}=2.50)$ were the major effects of the menace on farm land. Coping strategies adopted by the farmers included occupational diversification ( $\mathrm{M}=2.81)$, use of traditional rulers ( $M=2.65)$, use of fertilizers $(M=2.41)$, use of physical fight by farmers to drive cattle herders $(M=2.38)$, changing of time of planting $(M=2.31)$ and early harvesting method $(\mathrm{M}=2.28)$.
\end{abstract}

Keywords: Cattle menace; Effect; Farm land; Anambra state

\section{Introduction}

Land is probably the most important resources needed by man for his day-to- day existence. All human livelihoods and activities are directly depending on land at varying thresholds [1]. Builders, manufacturers, fishermen, miners, hunters and farmers among others have different specifications for land for their productions/services .Among all users, agricultural production exhibits the highest form of sophistication in terms of land use. Soil fertility is a limited factor to be considered in terms of land use principles and practices. Therefore, it is important to understand the extent of the damages done by the activities of Fulani herdsmen in the assessment of land use. Farmers-herdsmen are the most preponderant resource-land use in Nigeria. The necessity to provide crops, animals and raw materials for industries in order to meet over growing demand has led to the high degrees of land use [2]. The competitions between these two agricultural land user groups (Fulani and Farmers) have sometimes turned into serious social friction.

In Nigeria, production of arable crops is essentially the prominent feature of agricultural activities. Almost all farmers in Nigeria cultivate one or more arable crops for food and income. However, Nigerian agricultural production is dominated by rural-based small-scale arable crop producers, who account for about $80 \%$ of total food requirement [3]. Rashid [1] revealed that the average farm size in arable crop production was 4.58ha. Moreso, Central Bank of Nigeria (2005) indicated that 36.25 and 82.41 million hectares of arable crops were cultivated between 2004 and 2005, respectively. The most widely grown arable crop in Nigeria is maize which accounts for 6.6 and 7.5 million hectares in 2004 and 2005 respectively.

Cattle herding is dominated almost entirely by Fulani tribe in Nigeria [4]. According to him, the optimum Fulani cattle herd size lies between 80 and 100, with a preponderance of female over male at ratio $4: 1$. Cattle belonging to individual members are usually herded together. Fulani men possessing less than twenty cows are considered to be poor, while women having six cow are seen as rich. Women, however, own most of the small ruminants and all the poultries. Herding is dominated by the youths while decisions about grazing are made by the elderly family members [1]. The Fulani herdsmen make excellent use of sign language, the cane and verbal command to drive the animals.

According to Alhassan [5], the expansion of Fulani pastoralists into Nigeria is unknown. Fulani began to settle on the plains of Bauchi Emirate transcending onto the grass land of the Jos [6]. Competitions between pastoralists and farmers have been in existence since the beginning of agriculture. The increase or decrease in its intensity and frequency depend on 
economy, environment and other factors. However, increases in the herd size due to improved conditions of the cattle, compelled the pastoralists to seek for more pasture above their limited range. Climate change has therefore constituted a great threat there by exacting enough pressure on the land, thus powering the competition between them. However, improvement on human health and population has also increased a much greater pressure on the land, thus bringing vast area of land into cultivation. Sequel to this, farmers and pastoralists have engaged in fierce struggle for access to such valuable lands, which more often than not, result in increased conflicts and violence.

Research has shown that $75 \%$ of our daily food comes from 12 arable crops and five animal species, with just three arable crops (rice, maize and wheat) accounting for about $60 \%$ of the calories and proteins obtained from plants [7]. Arable crops enjoy remarkable dominance and significant roles in the socio-economic lives of both rural and urban people. The antagonism between land users (herdsmen and farmers) has invariably caused food insecurity in the both urban and rural communities where arable crops dominated the activities of the farmers. According to Gefu and Kolawole [8], competition for land between and within various users groups has been a threat to mankind since time immemorial. None-agricultural user group compete with agricultural user-groups, thus making agricultural soil more intense to soil infertility. The competition between these two agricultural land user- groups, however, has caused an overt manifestation of crop failures to the majority of farmers in Nigeria. In spite of the incessant soil lost and crop failures generated by Fulani herdsmen, it appears that there is a scarcity of information on the degrees of damages done by the Fulani herdsmen in the study area.

\section{Objective of the Study}

The major objective of the study was to examine the effect of cattle menace on farm land in Anambra State, Nigeria.

Specifically, the study was designed to:

a. Identify socio-economic characteristics of the crop farmers;

b. Determine the effect of cattle menace on the farm land; and

c. Identify coping strategies used by the farmers.

\section{Methodology}

The study area for this research was Anambra State, Nigeria. The State is located in the South-east of Nigeria. The State is bounded by Delta State to the west, Imo State to the south, Enugu State to the east and Kogi State to the north. Anambra State lies on the longitude $6035 \mathrm{E}$ and $7021 \mathrm{E}$ and latitude of 50 38N and 60 47E (Wikipedi Org/Wiki Anambrastate, 2010). The State comprises 21 Local Government Areas (LGAs) and four Agricultural Zones (AZs) - Aguata, Anambra, Awka and Onitsha. Anambra State occupies an area of 4,416 sq. km and has a population of $4,177,828$ out of which $2,117,984$ are male and $2,059,844$ female (NPC, 2006). The number of farm families is 338,721 with an average size of 6 persons per farm family or household.

The climate is typically equatorial with two main seasons, the dry and the rainy seasons. The vegetation consists of rainforest. Other parts consist of woody savannah and grasslands. Herding season in Anambra State begins from October to December which is the end of rainy season and the beginning of dry season. January to February is the harmattan season that is dominated by longer grazing hours, herd splitting and more frequent visit to stable water sources. The month of March and April are usually the toughest for herdsmen and cattle, because of the hottest period in the grazing calendar. May and June mark the end of dry season and vegetation begins to grow. Crops, livestock and fisheries are main stock in the farming system of the state. Major crops grown in the state among others include rice, cassava, yam, maize, okra, cocoyam, melon, cowpea and pigeon pea.

The population included all crop farmers in Anambra State. Multistage sampling and a combination of purposive and simple random sampling techniques were used in selecting a total sample size of 160 farmers. The first stage involved the purposive selection of two agricultural zones (Awka and Anambra) that are most associated with farmer-herder conflict in the state. In the second stage, two extension blocks were purposively selected from each selected zones due to their popularity in conflict effect with cattle herdsmen. This gave a total of four extension blocks involved in the study and they included Dunukofia and Awka North in Awka zone; Anambra East and Ayamelum in Anambra zone. The third stage involved the random selection of two extension circles from each of the selected extension blocks. This gave a total of eight extension circles and they included Omor and Omasi in Ayamelum block, Achala and Ugbene in Awka North block, Nando and Igbariam in Anambra East block, Ukwulu and Nawgu in Dunikofia block. In fourth stage, 20 crop farmers were selected from each circle using simple random sampling technique. This gave a total of 160 respondents that serve as sample size for the study.

An interview schedule was used for data collection and descriptive statistics such as percentage and mean were used in presenting data. To determine the effect of cattle menace on the farm land, farmers were asked to indicate on three points Likert- type scale the levels of damages on the soil fertility. Their response categories were; Very high $=3$, High $=2$, Not high $=1$. The values were added to get value of 6 which when divided by 3 gave a mean score of 2 .Variable with mean score less than 2 was regarded as" major effect" while variable with mean score equals to or above 2 was regarded as "minor effect on the farm land".

To identify coping strategies used, farmers were asked to indicate on 3-point Likert- type scale the extent of usage of the shortlisted coping variables. Their response categories were; Very effective=3, Effective=2, Ineffective=1. Then, the values 
were added to obtain a total of 6 which when divided by 3 gave a mean score of 2.Variable with mean score less than 2.0 was regarded as" ineffective strategy" while the variable with mean Results and Discussion score equal to or greater than 2.0 was regarded as" Effective strategy" used as a coping strategies for management of cattle menace on the farm land.

\section{Socio-economic characteristics}

Table 1: Percentage distribution of respondents according to socio-economic characteristics. Source: Field Survey, 2015.

\begin{tabular}{|c|c|c|c|}
\hline Variables & Frequency $(n=160)$ & Percentage & Mean (M) \\
\hline \multicolumn{4}{|c|}{ Sex } \\
\hline Male & 98 & 62.3 & \\
\hline Female & 62 & 38.8 & \\
\hline \multicolumn{4}{|c|}{ Marital Status } \\
\hline Single & 40 & 25 & \\
\hline Married & 94 & 58.8 & \\
\hline Widow & 10 & 6.3 & \\
\hline Divorce & 11 & 6.9 & \\
\hline Separated & 5 & 3.1 & \\
\hline \multicolumn{4}{|c|}{ Age } \\
\hline $21-30$ & 29 & 18.1 & \\
\hline $31-40$ & 96 & 60 & \\
\hline $41-50$ & 15 & 9.4 & 41.31 \\
\hline $51-60$ & 20 & 12.5 & \\
\hline \multicolumn{4}{|c|}{ Household Size } \\
\hline 2-Jan & 35 & 21.9 & \\
\hline 4-Mar & 66 & 41.3 & \\
\hline 6-May & 30 & 18.8 & 7 \\
\hline 8-Jul & 29 & 18.1 & \\
\hline \multicolumn{4}{|c|}{ Farm Size } \\
\hline$\leq 1 \mathrm{ha}$ & 38 & 23.3 & \\
\hline 1-2ha & 92 & 57.5 & 1.8 \\
\hline 3-4ha & 30 & 18.8 & \\
\hline \multicolumn{4}{|c|}{ Occupation } \\
\hline Full time farming & 98 & 61.3 & \\
\hline Trading & 18 & 11.3 & \\
\hline Civil servant & 44 & 27.5 & \\
\hline \multicolumn{4}{|c|}{ Crop Grown } \\
\hline Rice & 11 & 6.9 & \\
\hline Rice, cassava & 60 & 37.5 & \\
\hline Rice, cassava \& okro & 16 & 10 & \\
\hline Rice, cassava, okro \& maize & 30 & 18.8 & \\
\hline \multicolumn{4}{|l|}{ Rice, cassava } \\
\hline Okro, maize \& yam & 11 & 6.9 & \\
\hline Rice, cassava \& yam & 15 & 9.4 & \\
\hline Cassava \& okoro & 17 & 10.6 & \\
\hline \multicolumn{4}{|c|}{ Source of Farm Land } \\
\hline Rented & 98 & 61.3 & \\
\hline Inherited & 42 & 26.3 & \\
\hline Borrowed & 20 & 12.5 & \\
\hline
\end{tabular}




\section{Current Trends in Biomedical Engineering \& Biosciences}

\begin{tabular}{|c|c|c|c|}
\hline \multicolumn{5}{|c|}{ Source of Labor } & \\
\hline Family & 10 & 6.3 & \\
\hline Family/hired & 51 & 31.9 & \\
\hline Hired & 99 & 61.9 & \\
\hline Input dealers & 64 & 40 & \\
\hline Input dealers/others farmers & 96 & 60 & \\
\hline
\end{tabular}

Table 1 shows that majority (62.3\%) of the respondents were male and majority (58.8\%) of the respondents were married. Since the majority of the respondents were married, this could at the same time increase the release of family labour, thus making more hands available for agricultural production. Majority (60.0\%) of the respondents were between the age range of 31-40years while the mean age was 41.31 years. This implies that young people of economic active age dominated the study area. This finding is in consonance with Rashid [1] who found that farmers in Taraba State were in their active productive age.

Entries in Table 1 also reveal that greater proportion (41.3\%) of the respondents had household size between 3-4

persons while the mean household size was 7 persons. Majority $(57.5 \%)$ respondents cultivated $1-2$ ha while the mean farm size was 1.8ha. This shows that farmers in the State are small-scale farmers. This finding is in line with Mbanaso [9] who reported that farmers in the south-east zone were small-scale farmers. About $61 \%$ of the respondents were full time farmers while greater proportion $(37.5 \%)$ of the respondents grew rice and majority (61.3\%) acquired land on renting. Since majority of farmers acquire land by renting, this could increase the cost incurred on farming. Also, majority (61.9\%) of the respondents used hired labor as their source of labor and about $60 \%$ of the respondents used input dealers/other farmers as the major source of agro input.

Table 2: Percentage distribution of farmers according to soci-economic characteristics. Source: Field survey, 2015

\begin{tabular}{|c|c|c|c|}
\hline Variables & Frequency & Percentage & Mean (M) \\
\hline \multicolumn{4}{|c|}{ Educational Qualification } \\
\hline Non formal education & 9 & 5.6 & \\
\hline Primary school attempted & 10 & 6.3 & \\
\hline Primary school completed & 56 & 35 & \\
\hline Secondary school completed & 56 & 35 & \\
\hline OND/NCE & 23 & 14.4 & \\
\hline First degree/HND & 4 & 2.5 & \\
\hline M.Sc/Ph.D & 2 & 1.3 & \\
\hline \multicolumn{4}{|c|}{ Farming Experience (years) } \\
\hline 10-Jan & 98 & 61.3 & \\
\hline 20-Nov & 3 & 1.9 & \\
\hline $21-30$ & 32 & 20 & 16.4 \\
\hline $31-40$ & 27 & 16.9 & \\
\hline \multicolumn{4}{|c|}{ Access to credit } \\
\hline Yes & 99 & 61.9 & \\
\hline No & 61 & 38.1 & \\
\hline \multicolumn{4}{|c|}{ Institutional Source } \\
\hline Commercial bank & 25 & 15.6 & \\
\hline Agricultural bank & 26 & 16.3 & \\
\hline Microfinance bank & 48 & 30 & \\
\hline \multicolumn{4}{|c|}{ Non Institutional Source } \\
\hline Isusu clube & 65 & 40.6 & \\
\hline Money lender & 34 & 21.3 & \\
\hline \multicolumn{4}{|c|}{ Access to Extension Agent } \\
\hline Yes & 62 & 38.8 & \\
\hline No & 98 & 61.3 & \\
\hline
\end{tabular}


Entries in Table 2 show that greater proportion (35.0\%) each of the respondents completed primary and secondary school. The high number of literate people among the farming population shows that the majority of them are in a better position to adopt a better coping strategies with regards to the damages done by Fulani herdsmen. The mean year of farming experiences was 16.4 years. This implies that farmers had long period of farming experience, thus will increase their knowledge and experience on farming activities. Majority (61.9\%) of the respondents had access to credit in which $30 \%$ of the respondents sourced credit from micro-finance bank as either institutional source, while $40.6 \%$ of the respondents sourced credit from Isusu club as their non-institutional source, and majority (61.3\%) of the respondents had no access to extension service.

\section{Effect of cattle menace on the farm land}

Table 3: Mean distribution of respondents according to perceived effect of cattle menace on the farm land.

\begin{tabular}{|c|c|c|}
\hline Variables & Mean & Std. Deviation \\
\hline Loss of soil fertility & $2.59^{*}$ & 0.126 \\
\hline Environmental pollution & $2.50^{*}$ & 0.11 \\
\hline Crop failure $\backslash$ destruction & $2.50^{*}$ & 0.9 \\
\hline Erosion & 1.47 & 0.1 \\
\hline Chemical deterioration & 1.25 & 0.78 \\
\hline Loss of land & 1.09 & 0.069 \\
\hline Addition of nutrient to soil & 1 & 0 \\
\hline
\end{tabular}

Source: Field survey, $2015 ;{ }^{*}=\mathrm{M} \geq 2.0=$ major effect

Data in Table 3 indicate the degree of damages done by cattle in the study area. Loss of soil fertility $(M=2.59)$, environmental pollution $(M=2.50)$ and crop destruction/failure $(M=2.50)$ were the major effects of cattle menace on farm land, while erosion ( $M=1.47)$, chemical deterioration ( $M=1.25)$, loss of land $(M=1.09)$ and addition of nutrient $(M=1.00)$ with low weighted mean were perceived as the minor effect of cattle menace on the farm land. Under the activities of Fulani herdsmen, lost of soil fertility, environmental pollution, crop destruction, among others, were recorded as the effects on farm land and these could lead to substantial decrease in output with a serious implication on food security. This finding is in consonance with Salifu [10] who reported environmental pollution, crop destruction, among others as the effects of conflict on agricultural production.

\section{Coping strategies used by the farmers}

Data in Table 4 reveal the coping strategies for land used by farmers to avert menace of cattle in the study area. Coping strategies adopted by the farmers included occupational diversification $(M=2.81)$, use of traditional rulers $(M=2.65)$, use of fertilizers $(M=2.41)$, use of physical fight by farmers to drive out cattle rearers $(\mathrm{M}=2.38)$, changing of time of planting $(M=2.31)$ and early harvesting method $(M=2.28)$. These were regarded as very effective strategies. Ineffective coping strategies included use of soil treatment $(M=1.09)$, use of policemen $(M=1.06)$, change of farm land $(M=1.00)$ and use of fence $(M=1.00)$. Occupational diversification, use of traditional rulers, use of fertilizers, use of physical fight ,changing of time of planting, among others were very effective strategies in conflict management in the study area and this implies that these variables above are still relevant in conflict resolution in the study area. This finding, therefore disagreed with Rashid [1] who found that the most commonly used coping strategies by farmers in Kwara State was seeking help from friends and relations. In the same vein, the result also agreed with Adebayo \& Olaniyi [11] who found the role of traditional rulers as being important in the arbitration of conflict cases in Savanna area of Oyo State. The standard deviation values were less than one in all the variables. This implies that the responses of the respondents on these variables did not vary much from the mean, thus, can be useful in policy formulation [12-14].

Table 4: Coping strategies used by farmers.

\begin{tabular}{|c|c|c|}
\hline Variables & Mean & Std. Deviation \\
\hline Use of occupational diversification & $2.81^{*}$ & 0.95 \\
\hline Use of fertilizer & $2.41^{*}$ & 0.134 \\
\hline $\begin{array}{c}\text { Use of traditional ruler to ban them } \\
\text { from encroachment }\end{array}$ & $2.65^{*}$ & 0.125 \\
\hline $\begin{array}{c}\text { Use of physical fight by farmers to } \\
\text { drive them out of their farm }\end{array}$ & $2.38^{*}$ & 0.152 \\
\hline Use of early harvesting method & $2.28^{*}$ & 0.129 \\
\hline Changing of time of planting & $2.31^{*}$ & 0.118 \\
\hline Use of soil treatment & 1.09 & 0.52 \\
\hline Use of policemen & 1.06 & 0.062 \\
\hline Change of farmland & 1 & 0 \\
\hline Use of fence & 1 & 0 \\
\hline
\end{tabular}

Source: Field survey, $2015,{ }^{*}=\mathrm{M} \geq 2.0$ =effective strategy

\section{Conclusion and Recommendations}

The periodic struggle between farmers and Fulani herdsmen over a limited land has resulted into conflicts. These conflicts have seriously become more problematic and destructive since Fulani herdsmen do rely heavily on open and cultivated land to feed their cattle. The identified major effect of these menace on the farm land include loss of soil fertility, environmental pollution and crop destruction. The implications have automatically caused a lot of land damages and in the same vain compelled farmers to adopt various coping strategies such as occupational diversification, use of fertilizers to regain the fertility of the land, use of traditional rulers, use of physical fight and early harvesting method to cushion the effects of the menace.

In order to put the problems to an end, the following recommendations are made:

i. There is need to encourage education among two parties and this will bring a better perception for land use management. Here, farmers and herdsmen should be kept abreast with both principles of land use and management practices as to retain the fertility of the soil. 
ii. Use of traditional rulers and local leaders should be well articulated in finding lasting solution to conflicts between farmers and Fulani herders.

iii. There is need to utilize the educational role of extension services in herdsmen-farmer conflict through establishment of farmer-herders affair departments in the federal, state and local government ministries of agriculture. These departments should keep the records of events between these groups, undertake at regular intervals campaign for better awareness and compliance of stock routes among farmers and herdsmen to also teach farmers and herdsmen on issues of conflict prevention and need for co-operation and interdependence.

iv. The state governments being the owner of the land should demarcate grazing reserves for Fulani herdsmen along their grazing tracks in each state of the federation.

v. Agricultural extension service should collaborate with house of assembly in each of the states of Nigeria by providing realistic and practical inputs for legislations regarding arable land use and management of associated conflicts.

\section{References}

1. www.intechopen.com

2. Nyong A, Fiki C (2009) Droughts-Related Conflicts, Management and Resolution in the West African Sahel. Human Security and Climate Change International Workshop. Oslo; GECHS, CICERO and PR20.
3. Fayinka FA (2004) Food Security in Nigeria: Challenges under Democratic Dispensation. Paper presented at $19^{\text {th }}$ ARMT, Annual Lecture.

4. Iro I (1994) The Fulani Herding System Washington, African Development Foundation.

5. Alhassan U (2013) Herdsmen and Farmers Conflicts in North-Eastern Nigeria: causes, Repercussions and Resolutions. Academic Journal of Interdisciplinary studies. Published by MCSER-CEMAS-Sapienza University of Rome 2(5): 129-139.

6. http:/www.rogerbtech.infor/RBOP.htm

7. Lambrou Y, Laub R (2006) Gender Local Knowledge and Lessons Learnt in Documenting and Conserving Agro biodiversity. WIDER Research Paper, RP2106/69. Helsinki. UNU-WIDER.

8. http://d/c.dlib.indiana-edu/achive/0000023/00/gefuj080502.pdf

9. Mbanaso EO (2010) Adoption and Disadoption of sweet potato production and processing Technologies by farmers in South-Eastern Nigeria. PhD Thesis. Department of Agricultural Extension. University of Nigeria Nsukka, pp. 20-116.

10. Salifu DE (2013) Exploring resource use conflicts between crop farmers and fulani herders in Kogi State, Nigeria. PhD Findings. Department Of Agricultural Extension University of Nigeria, pp. 62-94.

11. Adebayo 00, Olaniyi OA (2008) Factor associated with pastoral and crop farmers conflict in derived savanna zone of Oyo State, Nigeria. Journal of human ecology 23(1): 71-74.

12. Anambra State ADP (ASADEP) (2011) End of year 2011 report.

13. Central Bank of Nigeria, CBN, (2005) Annual Reports and Statement of Accounts. Abuja, Nigeria.

14. http://www.npc.gov

Your next submission with Juniper Publishers will reach you the below assets

- Quality Editorial service

- Swift Peer Review

- Reprints availability

- E-prints Service

- Manuscript Podcast for convenient understanding

- Global attainment for your research

- Manuscript accessibility in different formats

( Pdf, E-pub, Full Text, Audio)

- Unceasing customer service

Track the below URL for one-step submission

https://juniperpublishers.com/online-submission.php 